\title{
Linking Agriculture with Health through Genetic and Agronomic Biofortification
}

\author{
Anteneh A. Melash, Dejene K. Mengistu*, Dereje A. Aberra \\ Department of Dryland crop and Horticultural Sciences, Mekelle University, Mekelle, Ethiopia \\ Email: *dejenekmh@gmail.com
}

Received 13 April 2016; accepted 17 May 2016; published 20 May 2016

Copyright @ 2016 by authors and Scientific Research Publishing Inc.

This work is licensed under the Creative Commons Attribution International License (CC BY).

http://creativecommons.org/licenses/by/4.0/

(c) (i) Open Access

\begin{abstract}
Malnutrition and associated health problems are partly related to minerals and vitamins deficiencies where anemia and stunting are the major diseases affecting nearly half of pregnant women and about $20 \%$ children under age of five, respectively in developing countries. Despite the significant progress made in recent decades, prevalence of stunting in Ethiopia remains high (44\%, among children) that necessitate the country yet to make significant investment in nutrition and health. Strategies designed to overcome the problem range from micronutrient rich foods supplement to complementing foods with vegetables and fruits. However, such strategies are expensive as well as not sustainable to reach the poor households of developing countries. The persistence of the problem calls for agriculture based alternative solutions such as agronomic biofortification and micronutrients biofortification through plant breeding. Utilization of crop wild relatives, local landraces and old cultivars are proved to contain sufficient grain micronutrients and their utilization in breeding programs can solve the deficiency of micronutrients such as zinc and iron. Similarly, agronomic biofortification could improve grain $\mathrm{Zn}$ and Fe contents in several folds. Application methods and crop developmental stages during which fortification applied significantly determine the efficiency of fortification. Foliar application at heading and milking stages could accumulate very high $\mathrm{Zn}$ and $\mathrm{Fe}$ in cereal grains. The synergistic effect of genetic and agronomic fortification could also be utilized to produce $\mathrm{Zn}$ and Fe rich food crops. Hence, linking agriculture with nutrition and health could offer equitable, effective, sustainable and cheap solutions to micronutrients malnutrition and their deficiency related health problems.
\end{abstract}

\section{Keywords}

Agriculture, Linkage, Micronutrients, Malnutrition, Biofortification

"Corresponding author. 


\section{Introduction}

There is growing interest in the role of micronutrients (essential trace elements and vitamins) in optimizing health, and in prevention or treatment of disease [1]. Micronutrients play crucial roles in human nutrition, including the prevention and treatment of various diseases and conditions, as well as the optimization of physical and mental functioning. Globally, in Asia, Africa and Latin America countries, deficiency for micronutrients such as iron, zinc, folic acid and beta-carotene is the most prevalent, affecting over 2 billion people [2]; of which the highest prevalence is reported in sub-Saharan Africa [3]. For these reasons, understanding micronutrients is critical for anyone seeking to maintain or improve the nutritional security which in turn ensures health security. The essential micronutrients, which are obtained from daily dietary intake, are important to keep active metabolic processes in human [4]. Micronutrients rich staple foods have potential to tackle micronutrients deficiency and offer a sustainable solution to the nutrition and health problems [5]. Major source of calories intake basically comes from cereals, pulses and animal products, particularly in developing countries, but most of the cereal crops are deficient or with suboptimal content of micronutrients. Furthermore, the cultural processes through which cereals have to go before consumption, such as de-hulling and milling, reduce their content [6]-[8].

\subsection{Micronutrients Deficiency and Associate Socioeconomic Risks}

People from a poorer background, who basically deprived off fresh fruits and vegetables, have a poorer intake of nutrients as a result of a complex interaction between social and economic circumstances [1]. Such groups of people usually include children and women, who can benefit from some form of micronutrient supplement to improve their dietary intake. Studies confirm that these groups in developing countries are subjected to risks associated with deficiencies in micronutrients [4] [9] [10]. Among mineral micronutrients required for healthy life, zinc is often deficient in human and animals diets [4]. This deficiency in zinc could result in impaired immune function, children's stunted growth and adverse pregnancy outcome in women [9]. Likewise the absence of iron also leads to numerous physiological diseases like anemia and neurodegenerative diseases [10]. Zinc deficiency may deter normal growth. About $20 \%$ of children under age of five can be subjected to the deficiency of zinc, iron and other important minerals and vitamins [11]. According to FAO [3], this figure is even worse in Ethiopia because more than $50 \%$ of children and $25 \%$ of women clinically tested anemic due to iron deficiency; and $\mathrm{Ku}$ mera et al. [12] reported 57.4\% of Zn deficiency among pregnant women, who attended antenatal care at Gonder hospital, Ethiopia.

\subsection{Prevalence of Micronutrient Deficiency in Ethiopia}

Micronutrients deficiency and associated health risks are highly prevailing in Ethiopia, as various studies confirm [13]-[15]. It has been revealed that the bioavailability Zn and Fe in the dietary intake of more than 50\% of women of childbearing age [16] is questionable. The associated problems to deficiency in micronutrients include anemia (Fe deficiency), goiter (iodine deficiency), and stunted growth of children. Iron deficiency anemia (IDA) is among the major public health and nutritional problems identified in Ethiopia. According to Ethiopian Demographic and Health Survey [13], many women at reproductive age $(16.6 \%-30.4 \%)$ were tested positive for anemia. The survey conducted on pregnant women also reported a high (30.6\%) level of anemia prevalence [17]. IDA is defined as a level of hemoglobin less than $11 \mathrm{~g} \cdot \mathrm{dl}^{-1}$ and is serious in pregnant women because it decreases hemoglobin ability to carry oxygen during pregnancy [18].

Malnutrition partly associated with micronutrients has been affecting children under age of five. According to DHS [13], the prevalence is more in rural areas (45\%) than urban areas (35\%), probably due to supplementary nutrient provision to urban children. Figure 1 presents the regional distribution of stunting in children of Ethiopia associated to malnutrition. The prevalence observed higher in Amhara, Tigray, Afar and BenishangulGumuz presumably associated with the degradation of agricultural lands. The stunting provenance mainly associated with Zn, Fe and other micronutrients deficiency in their daily meal [12] [13]. Zn deficiency could also be expressed in several diseases such as dermatitis, diarrhea, alopecia and loss of appetite and intestinal parasitic infection [12] [83]. The prevalence of zinc deficiency among pregnant women was 57.4\% [12]. Cognizant to the intensity of the problem at the grass root level, this review will therefore consider the potential of biofortification in improving micronutrients concentration in cereal crops, and discuss the contribution of biofortification to the issue of addressing nutritional security of agrarian communities. The review will focus only on Zinc and iron 


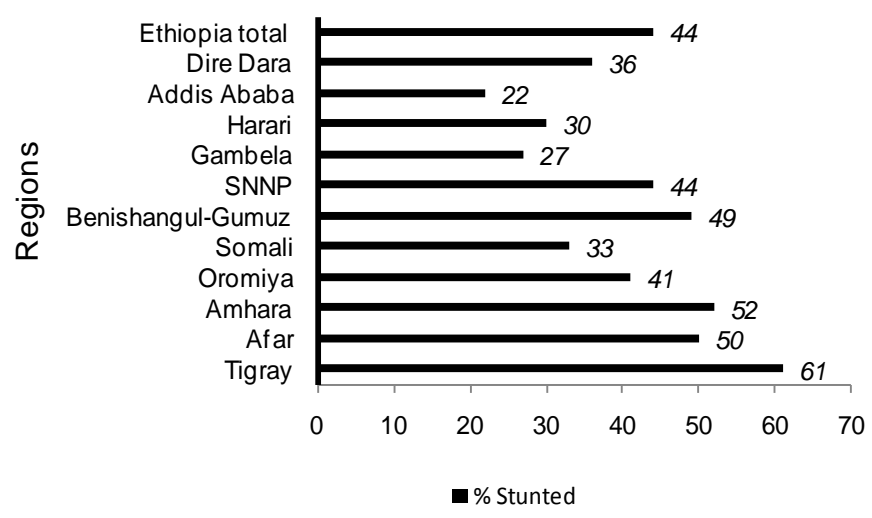

Figure 1. Stunting of children under five aged by regions of Ethiopia (Source: DHS 2011).

mineral nutrients, for which states, have been clearly reported and on which we started testing for durum wheat through agronomic foliar fortification.

\section{Factors Aggravating Micronutrients Deficiency}

\subsection{Reliance on Few Crops}

Modernization of agriculture does not only affect the diversity of crops but also the diversity of nutrition. Crop production geared towards high yielding cereal crops mainly wheat, maize and rice could significantly reduce the production of nutritionally richer grains [4] [82]. This reliance on few crops is the major reason for widespread of Zn and Fe deficiencies [19]-[21]. Exploiting genetic diversities from crop wild relatives, landraces and old cultivars in crops breeding programs is suggested to improve the micronutrients content of modern varieties.

\subsection{Soil Factors}

Selective application of particular fertilizers for increased crop productivity and restoration of heavily degraded soils could limit bioavailability of certain micronutrients through fixation. For instance, high level of available phosphorous in the soil is usually ended up with zinc deficiency [22] [23]. An important point other than concentration per se in Fe and $\mathrm{Zn}$ in grains is their bioavailability [24].

\subsection{Action of Anti-Nutritional Compounds}

The efficiency of micronutrients absorption from a diet depends upon the amounts consumed (decreases with an increase in amounts consumed) and the presence of dietary phytate [25] [26]. Phytate forms insoluble complexes, for instance with Zn, that cannot be digested or absorbed because of the absence of intestinal phytate enzymes in humans [27]. Bindra et al. [28] concluded that diets with phytate-to-Zn molar ratios above 15 are associated with $\mathrm{Zn}$ deficiency in humans. If we consider for example wheat, the main source of human daily calories, its zinc and iron contents usually decrease because of its richness in ant-nutritional compounds such as phytic acid and phenols [4].

\subsection{Food Processing Cultural Practices}

Cultural practices such as de-hulling, milling, fermenting and cooking are applied cultural practices to cereals before they are consumed. These cultural practices are usually practiced to improve the texture and flavor of the final food produced. However, these cultural practices are also known to remove the important minerals, vitamins and other micronutrients thus resulting in marked reduction of their concentration in the processed food [4] [6]-[8]. According to Ozturk et al. [29], aleurne layer and embryo of wheat seeds contain ten-fold Zn concentration compared to its endosperm concentration. Hence, removing of the Zn-rich layer during processing will result in significant reduction $\mathrm{Zn}$ content in the final food. 


\section{Biofortification to Ensure Nutritional Security}

The concern of nutritional security has gain momentum in the world at the same pace as food security. To ensure nutritional security, linkage of agriculture to nutrition and revisiting policy formulation in agriculture, nutrition and health is needed [30]. This has motivated crop experts to search out sustainable ways of improving nutritional contents of their crops. Among agronomic managements, grain biofortification is proved to improve the concentration of micronutrients in cereal grains [24] [31] [32]. Biofortification is defined as "the process of improving the concentration of essential minerals in the edible portion of staple food cops through agronomic practices as well as genetic selection" [42]. Biofortification can avoid the problem of micronutrient malnutrition by increasing the crop micronutrient concentration through improving their amount and bioavailability in the edible portion of the crops. The benefits of these nutritionally enriched/dense crops will be sustainable with little further investment [33]. Where micronutrients are deficient and associated health risks are high biofortification of cereal crops with the deficient micronutrient is perceived as cost effective, easily accessible and sustainable way of combating the problem.

\section{Sustainable Approaches to Ensure Nutritional Security}

'Nutrition Security', is an access to adequate nutritional status in terms of protein, energy, vitamins, and minerals for all household members at all times [34] and thus in principle it is more than food security [35]. This means that access to food does not guarantee nutritional security. Important components of nutritional security such as the daily intake of micronutrients are usually missed either unknowingly or due to lack of access. As indicated above, the problem aggravates in rural communities of developing countries, whose major sources of daily calories of mineral and protein is dependent on crop commodities such as cereals. Hence, improving the nutritional content of their agricultural produces could be the best and sustainable way of ensuring nutritional security [33] [36] [37].

\section{Biofortification Produces Micronutrients Denser Grains}

The solution for the globally widespread problem of essential micronutrients deficiency was sought by different expertise including physicians and nutritionists through food enrichments by the essential micronutrients [9] [38]. Salt fortification with Fe and iodine [39], cereal-based traditional foods enrichment with vitamins and minerals both at home and factories [30] [71] and improving dietary composition by adding meat, fruits and vegetables [40] are among implemented solutions. These solutions, however, basically targets the beneficiaries in urban and per-urban areas and left out the rural majority, particularly, in developing countries [41]. Besides the approaches are labor demanding [24] and costly to be afforded by the poor [4]. These limitations forced agronomists, soil scientists and breeders to think of a strategy that is cost and labor effective and sustainable to tackle the problem of micronutrients deficiency. Biofortification become an important science to produce $\mathrm{Zn}$ and Fe denser cereal grains. This approach was proved to improve the content of selected micronutrients in staple food crops such as rice, wheat, maize and pearl millet [24] [30] [33] [36] [37]. Biofortification ensures nutritional security in two practical ways. The first is by ensuring the enrichment of bio-available micronutrient into the edible portion of the plant through genetic engineering as well as breeding [42] and second by improving the concentration of the deficient micronutrient of a crop through fertilizer application [5], which is termed as "agronomic fortification”. We provide a brief discussion on success story of this technology in this review paper.

\subsection{Genetic Biofortification}

It involves both traditional breeding as well as modern biotechnology application to improve the nutritional content of crops. Several projects, such as African biofortified Sorghum, have attempted genetic biofortification to develop crop varieties capable of producing grains denser in $\mathrm{Zn}$ and other micronutrients [43]. In rice, Fe content enhancement was achieved by improving the uptake from soil and by increasing its absorption and storage [44]-[46]. Improving nutritional quality of staple crops through genetic biofortification is implicitly reaches the poor because staple foods predominate in the diets of the poor and after the one-time investment to develop seeds that fortify themselves, recurrent costs are low, and germplasm can be shared internationally [47].

The success of genetic fortification depends on crop types and varieties under consideration. The responses to applied $\mathrm{Zn}$ and Fe containing fertilizers and their efficiency in accumulating the micronutrients in crop grains 
could greatly vary from crop to crop and variety to variety within crop. For instance, Conti et al. [48] reported that durum wheat varieties tend to accumulate more $\mathrm{Zn}$ and Fe than bread wheat varieties. This feature tends to hold true for cadmium as well. The findings of different scholars indicate that old crop cultivars, wild relatives and landraces have displayed wider variation in translocating micronutrients than the modern varieties of wheat [18] [49] [50]. Table 1 presents the range of $\mathrm{Zn}$ content ( $\mathrm{mg} / \mathrm{kg}$ ) of the different crops at different advancement level under natural condition. For wheat, it was noticed that grain in $\mathrm{Zn}$ concentration greatly varies for durum and bread wheat. This variation also associates with the status of improvement of each ploidy. The wider range (Table 1 and Table 2) for the value of $\mathrm{Zn}$ and Fe could be associated with the fertility status of the soil [60] and nutrient uptake potential of each variety [61] [62], and the precipitation or adsorption of $\mathrm{Zn}$ with various soil components, depending on the $\mathrm{pH}$ and redox potential [31] and previous crop grown [63].

Although plant breeding is the most sustainable solution to the problem, developing new micronutrient-rich plant genotypes is a protracted process and its effectiveness can be limited by the low amount of readily available pools of micronutrients in soil solution [37] and micronutrients rich crops developed through this approach are subjected to resistance of adoption in a sense that the products are genetically modified in several countries [64]. Moreover, developing crops through breeding needs fairly long time and combining high yield with high Zn or Fe concentration in grain needs still more time [24]; and also achieving high Fe levels in grains through breeding is not easy due to its lower bioavailability [19]. Because of these limitations, an alternative approach that increases micronutrients concentration in grains within a short period of time is essential.

\subsection{Agronomic Biofortification}

The concentration of essential micronutrients in cereal grains can be agronomically managed. The management

Table 1. The variation for Zinc grain concentration of various crop genotypes, documented in various studies.

\begin{tabular}{|c|c|c|}
\hline Crop type and status of improvement & Grain [Zn] (mg/kg) & Literature \\
\hline $\begin{array}{l}\text { Tetraploid wheat } \\
\text { Durum wheat }\end{array}$ & $17.0-28.0$ & Cakmak et al. [51] \\
\hline Old cultivars & $33.7-41.4$ & Ficco et al. [49] \\
\hline Modern varieties & $28.5-46.3$ & Ficco et al. [49] \\
\hline $\begin{array}{l}\text { Advance lines } \\
\text { Landraces }\end{array}$ & $\begin{array}{l}29.1-40.9 \\
44.9-49.8\end{array}$ & $\begin{array}{l}\text { Ficco et al. (2009) } \\
\text { Monasterio and Graham [52] }\end{array}$ \\
\hline $\begin{array}{l}\text { Hexaploid wheat } \\
\text { Bread wheat }\end{array}$ & $8.0-61.0$ & $\begin{array}{l}\text { Zhao et al. [53]; Abrar et al. [54] } \\
\text { Cakmak et al. [55] }\end{array}$ \\
\hline Advance lines & $29.0-39.5$ & Velu et al. [50] \\
\hline Old cultivars & 38.1 & Abrar et al. [54] \\
\hline $\begin{array}{l}\text { Wild emmer wheat } \\
\text { Maize } \\
\text { Teff } \\
\text { Sorghum }^{\gamma}\end{array}$ & $\begin{array}{l}39.0-115 \\
15.0-47.0 \\
11.0 \\
1.12-7.58\end{array}$ & $\begin{array}{l}\text { Gomer-Becerra et al. [70] } \\
\text { Ortiz-Monasterio et al. [20], Valéria et al. [57]; } \\
\text { Amede et al. [56] } \\
\text { Badigannavar et al. [58], Kayode et al. [59] }\end{array}$ \\
\hline
\end{tabular}

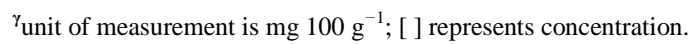

Table 2. The variation of grain iron concentration in various crop genotypes, documented in various studies.

\begin{tabular}{|c|c|c|}
\hline Crop type and status of improvement & Grain [Fe] (mg/kg) & Literature Sources \\
\hline Durum wheat & $23.0-73.0$ & $\begin{array}{l}\text { (Cakmak et al., [21]; Zhang et al. [32]; Velu et al. [79]; } \\
\text { Gao et al. [80]; Narwal et al. [81] }\end{array}$ \\
\hline Durum (landrace) & $38.5-47.9$ & Abrar et al. [54]; Monasterio and Graham, [52] \\
\hline Bread wheat & 47.5 & Abrar et al. [54] \\
\hline Maize & $11.0-39.0$ & Valéria et al. [57]; Ortiz-Monasterio et al. [20] \\
\hline Teff & 115 & Amede et al. [56] \\
\hline Sorghum $^{\gamma}$ & $1.1-9.54$ & Badigannavar et al. [58]; Kayode et al. [59] \\
\hline
\end{tabular}

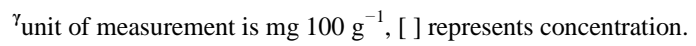


of $\mathrm{Zn}$ and Fe, the most globally emerged deficient micronutrients, are become the concern for agronomists and soil scientists and each are devising mechanisms of alleviation of their deficiencies. Agronomic biofortification is perceived as a best approach of linking agriculture with nutrition and health [24] [30]. Agronomic fortification of cereal crops can be cost effective and sustainable way of agricultural approach to combat micronutrient malnutrition problem, particularly for agrarian communities.

\section{Determinants of Agronomic Fortification Efficiency}

\subsection{Application Methods}

The effectiveness of agronomic fortification is dependent on application methods. The various methods of $\mathrm{Zn}$ application may differentially influence yield and grain Zn concentration [19] [32]. So far, application methods such as soil application (during planting), seed dressing and foliar application were tested for their effectiveness in increasing Zn and Fe concentration in the grain [37] [65]-[67]. Soil based application tends to increase grain yield rather than its micronutrient content [68]. Foliar application was found to be more effective in increasing grain $\mathrm{Zn}$ and Fe concentration in different crops. In wheat, soil based application of $\mathrm{Zn}$ was reported to be less effective in increasing grain compared to the foliar application, which remarkably increase grain Zn concentration [32] [69]. For instance, Yilmaz et al. [67] reported three-fold increase of grain $\mathrm{Zn}$ concentration in durum wheat because of foliar application. Figure 2 summarizes result reported by similar authors for the two wheat ploidy (durum and bread).

The figure clearly depicts that i) the evaluated methods of $\mathrm{Zn}$ application gave different result and ii) durum wheat responded well than bread wheat. Mao [66] has also reported a positive grain in grain Zn concentration due to foliar application of Zinc sulfate in winter wheat. In his study, a $10 \mathrm{mg} \cdot \mathrm{kg}^{-1}$ of grain Zn concentration was obtained solely from application method. Zn concentration in grain is, however, not linearly associated with either soil or foliar application of Zn but could also be influenced by initial Zn content of the soil and dosage of applied Zn [69]. Their trial demonstrated that grain Zn concentration of durum wheat varies with the initial amount of $\mathrm{Zn}$ available in the soil whereby supplementary $\mathrm{Zn}$ application had positive impact on Zn deficient soil (Figure 3).

For iron, similar situations were reported by scholars. Narwal et al. [68] observed that foliar application of $\mathrm{Fe}^{2+}$ was more effective than soil application to improve grain Fe concentration in wheat. The found that foliar application has increased grain iron concentration from 1.0 to $2.3 \mathrm{mg} / \mathrm{kg}$. Grain Fe concentration is not only affected by the application method but also by sources of iron fertilizers [72] and application dose [73]. For instance, the findings of Ghafari and Razmjoo [73] indicated that increasing iron application dose up to 8g per litter could not only increase grain iron concentration in durum wheat but also its grain carbohydrate and protein contents, which are important quality parameters for durum wheat. The positive effect on iron fertilization on durum wheat protein content was also reported by Zeidan et al. [74]. Thus, the application of micronutrients could also improve the market acceptance of commercial crops like durum wheat and can ensure economic benefit of farming communities besides nutritional security.

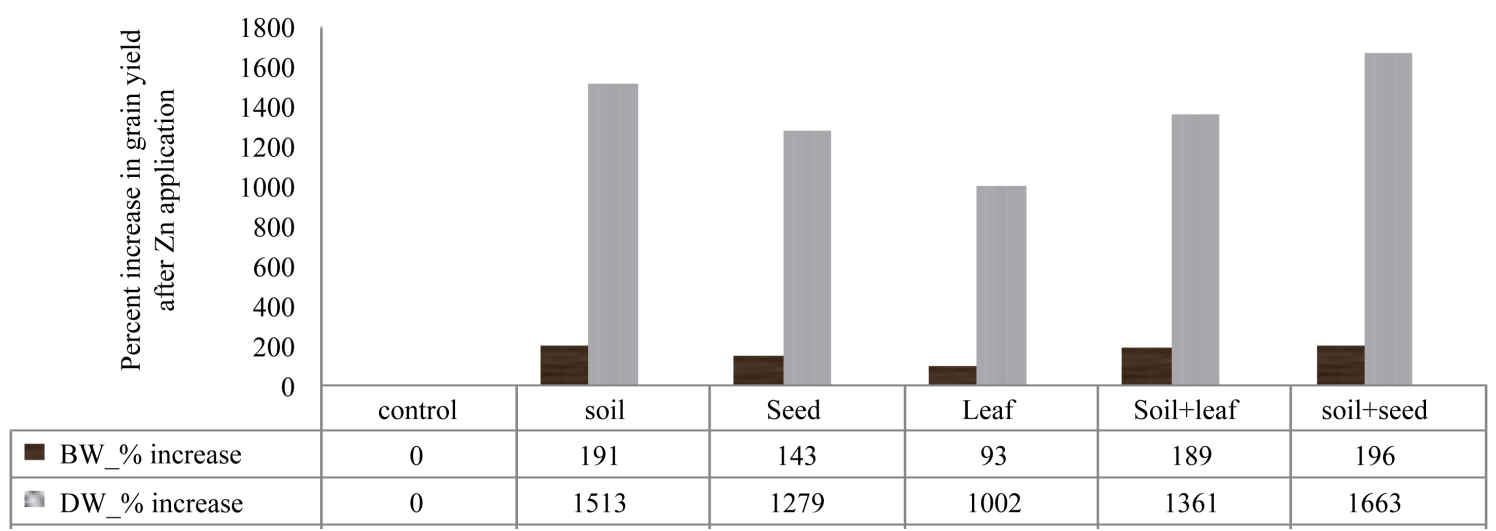

Figure 2. Grain yield increment (\%) of bread wheat (BW) and durum wheat (DW) varieties after different application method of Zn (adopted in modified form from Yilmaz et al. [67]). 


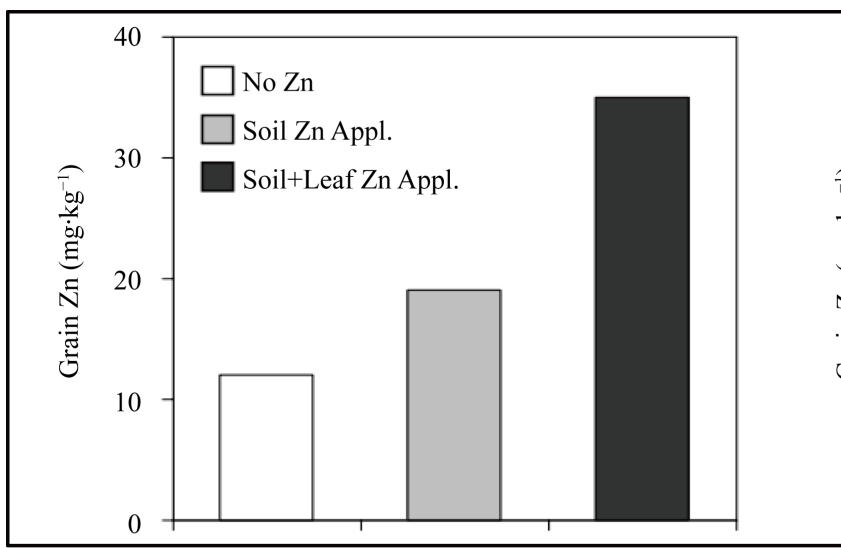

(a)

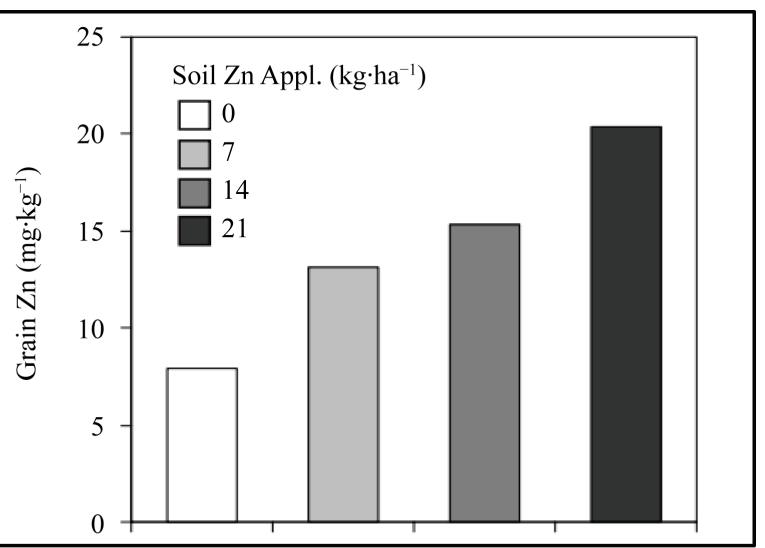

(b)

Figure 3. Changes in grain zinc concentrations of durum wheat after soil and foliar application of zinc sulfate (a) and application of increasing amount of zinc to soil (b) from field experiments (Source: Cakmak et al. [69]).

\subsection{Crop Developmental Stages}

We have seen that foliar application is more effective in improving grains micronutrient content than soil application even though the combination of soil plus foliar works better for some crops. Nevertheless, the effectiveness of foliar application is quite dictated by crop developmental stage for accumulation of micronutrients in the grain. Hence, the knowledge of crop developmental stages during which foliar application of micronutrients result in higher grain accumulation is very crucial. Application of $\mathrm{Zn}$ during reproductive stages at heading and early milk stage [69] and at milky dough stage [75] were reported to accumulate greater amount of grain zinc than its application at booting and stem elongation stages of the crop. Figure 4 presents the effect of crop developmental stages on the effect of foliarly applied ZnSO.7HO on the amount of Zn concentration in the grain of two wheat varieties, Konya and Adana. The figure depicts that Zn concentration in the grain is the function of both varieties and application time.

The figure demonstrates that the knowledge of crop growth stage at which micronutrients should be foliarly applied is fundamental to obtain $\mathrm{Zn}$ reach grain. For Fe, similar effect was reported in various literatures. For instance, Maralian [76] reported a 64.4\% increase in grain Fe concentration due to foliar application over the control. The effectiveness of foliar application during milking stage of crops could probably associated with the easy remobilization of micronutrients due to active photo-assimilates allocation to reproductive sink organs. Their strength in competition for available resources would be high compared to other organs. In line with this, Ozturk et al. [29] noticed that wheat crop mobilize higher amount of zinc during milk stage compared to its mobilization during other stages. Haslett et al. [77] also reported that vascular (phloem) mobility of Zn is stronger for foliar application during reproductive stages.

\section{Genetic and Agronomic Biofortification Could Exhibit Synergetic Effect}

The benefits in increasing $\mathrm{Zn}$ and $\mathrm{Fe}$ in grain of crops from genetic and agronomic biofortifications were presented in the above sections. But, can we further capitalize on this benefit by combining the two approaches to further enhance micronutrients accumulation in grains? Various previous findings suggest the possibility of further micronutrients enrichment in grains from combination of the two agricultural approaches. For instance, Mathpal et al. [65] observed very notable differences between two wheat cultivars in their grain Zn accumulation (Figure 5).

The nutrients accumulation capacity of genotypes greatly varies where landraces and old cultivars are more efficient that modern crop varieties (Table 1 and Table 2). The success of improving mineral nutrient through agronomic fortification is determined by the available genetic variation in a given crop varieties. So selecting crops that are genetically efficient in accumulating micronutrients in their grain would make agronomic fortification more successful [78]. The selection of right varieties coupled with application of the right fertilizer type using appropriate application method could enhance the concentration of targeted micronutrient in edible parts 


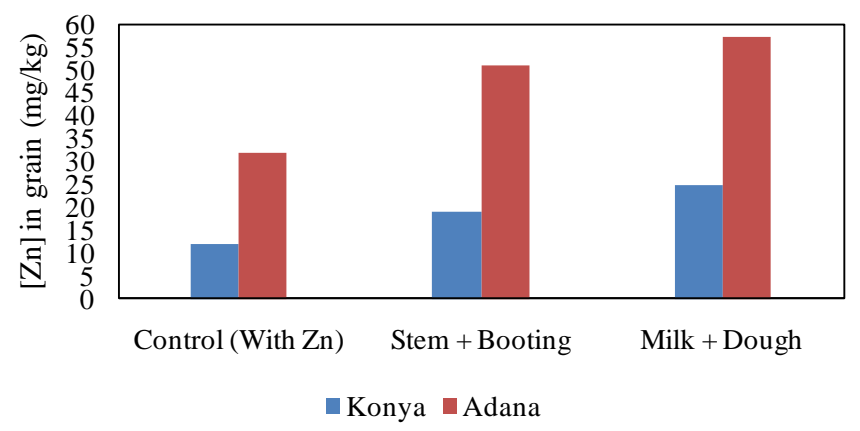

Figure 4. Zinc concentrations of wheat grain grown under field conditions with foliar spray of $0.5 \% \mathrm{ZnSO}_{4} \cdot 7 \mathrm{H}_{2} \mathrm{O}$ at different growth stages (Data was extracted from Cakmak [75]).

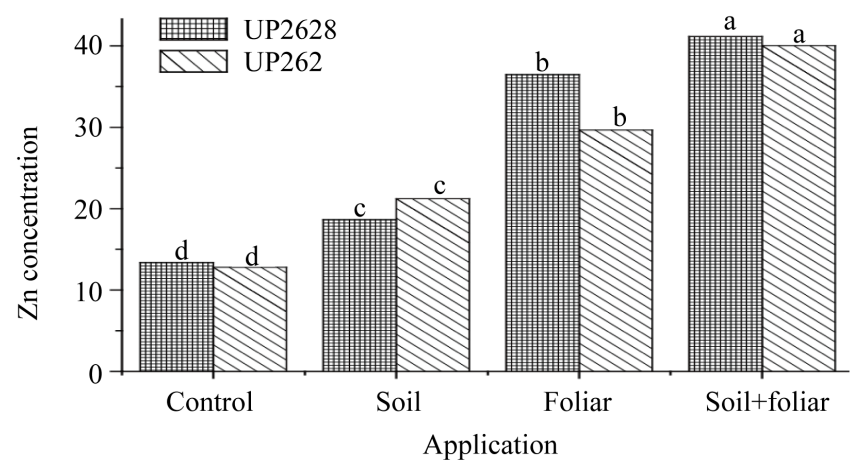

Figure 5. Differential response of two contrasting wheat genotypes in grain $\mathrm{Zn}$ concentration $(\mu \mathrm{g} / \mathrm{g})$ under different $\mathrm{Zn}$ application methods. Dissimilar letters over histograms indicate significant difference at $p<0.05$. (Adopted from Mathpal et al. [65]).

of several crops [58] [66]. This implies that genetic and agronomic biofortifications could synergistically improve grain concentration of different micronutrients (Figure 5). This actually requires the knowledge of genetic potential of crop under consideration to respond to the applied fertilizer and accumulate the desired amount of micronutrients in its grain. The review clearly demonstrated that biofortfication could improve $\mathrm{Zn}$ and Fe concentrations in grains of various cereal crops. For instance, Cakmak et al. [69] indicated that $\mathrm{Zn}$ foliar application at different development stages improved Zn concentration in wheat grain from 23\% to 34\% over untreated plots. Similar study showed that foliar application of Zn could also improved grain Fe concentration. Breeding for micronutrients could also increase grain concentration of $\mathrm{Zn}$ and Fe in many staple crops. For instance, Monasterio and Graham [52] have screened wheat lines having 41\% more Zn and 30\% more Fe grain concentration from their breeding program designed to breed for trace elements.

\section{Conclusion}

Mineral micronutrients associated malnutrition and related health problems are major concern of national and international health care organizations. Despite due attention was given to this problem by physicians and nutritionists, the problem still remains among the major risk factor to some social groups particularly children and pregnant women. This review clearly demonstrated that biofortification, either genetic or agronomic, could provide cheap and sustainable solution to micronutrients deficiency problems. Biofortification is a pragmatic, inexpensive and an easy method of micronutrient delivery especially for smallholder households in low income countries such as Ethiopia. The effectiveness of $\mathrm{Zn}$ and Fe concentration in cereal crops is highly influenced by application method and application time with reference to crop development stage. Foliar application during post-anthesis stages, i.e. heading and milking stages, was proved to efficiently accumulate mineral micronutrients in the grain. The synergistic effect of genetic and agronomic biofortification could also be exploited to 
sufficiently accumulate micronutrients in grain of major cereal crops to alleviate mineral nutrients related malnutrition and associated health risk. Hence, linking agriculture with nutrition and health could offer equitable, effective, sustainable and cheap solutions to micronutrients malnutrition and their deficiency related health problems. Gearing future research towards agronomic and genetic biofortification could potentially solve health problems associated with micronutrients deficiency in sustainable way and could also be most affordable approach for the majority of rural communities in developing countries.

\section{Acknowledgements}

This review paper benefited a lot from the work of other scholars working around the subject matter and hence we give our sincere thanks though we have provided full reference to information used. The financial support from RUFORUM to carry out field research work on durum wheat-micronutrients interaction, which has triggered this review concept, is greatly appreciated.

\section{Conflict of Interest}

The authors declare that there is no conflict of interest.

\section{References}

[1] Shenkin, A. (2006) Micronutrients in Health and Disease. Postgraduate Medical Journal, 82, 559-567. http://dx.doi.org/10.1136/pgmj.2006.047670

[2] Darnton-Hill, I., Bloem, M. and Chopra, M. (2006) Achieving the Millennium Development Goals through Mainstreaming Nutrition: Speaking with One Voice. Public Health Nutrition, 9, 537-539. http://dx.doi.org/10.1079/phn2006965

[3] FAO (2008) The State of Food Insecurity in the World: High Food Prices and Food Security—Threats and Opportunities. Rome.

[4] Welch, R. and Graham, R. (2004) Breeding for Micronutrients in Staple Food Crops from a Human Nutrition Perspective. Journal of Experimental Botany, 55, 353-364. http://dx.doi.org/10.1093/jxb/erh064

[5] Welch, R. (2002) The Impact of Mineral Nutrients in Food Crops on Global Human Health. Plant and Soil, 247, 83-90. http://dx.doi.org/10.1023/A:1021140122921

[6] Fabbri, A. and Crosby, G. (2015) A Review of the Impact of Preparation and Cooking on the Nutritional Quality of Vegetables and Legumes. International Journal of Gastronomy and Food Science, Available online 24 November 2015, In Press. http://dx.doi.org/10.1016/j.ijgfs.2015.11.001

[7] Pereira, E., Carvalho, L., Dellamora-Ortiz, D., Cardoso, F., Carvalho, J., Viana, J., Freitas, S. and Rocha, M. (2013) Effects of Cooking Methods on the Iron and Zinc Contents in Cowpea (Vigna unguiculata) to Combat Nutritional Deficiencies in Brazil. Food \& Nutrition Research, 58, 20694.

[8] Buri, R., Von, R. and Gavin, M. (2004) Description and Characterization of Wheat Aleurone. Cereal Foods World, 49, 274-281.

[9] Hess, S. and King, J. (2009) Effects of Maternal Zinc Supplementation on Pregnancy and Lactation Outcomes. Food and Nutrition Bulletin, 30, S60-S78. http://dx.doi.org/10.1177/15648265090301S105

[10] Andreini, C., Banci, L. and Rosato, A. (2006) Zinc through the Three Domains of Life. Journal of proteome Research, 5, 3173-3178. http://dx.doi.org/10.1021/pr0603699

[11] Prentice, A., Gershwin, M., Schaible, U., Keusch, G., Victoria, L. and Gordon, J. (2008) New Challenges in Studying Nutrition Disease Interactions in the Developing World. The Journal of Clinical Investigations, 118, 1322-1329. http://dx.doi.org/10.1172/JCI34034

[12] Kumera, G., Awoke, T. Melese, T., Eshetie, S., Mekuria, G., Mekonnen, F., Ewunetu, T. and Gedle, D. (2015) Prevalence of Zinc Deficiency and Its Association with Dietary, Serum Albumin and Intestinal Parasitic Infection among Pregnant Women Attending Antenatal Care at the University of Gondar Hospital, Gondar, Northwest Ethiopia. BMC Nutrition, 1, 31. http://dx.doi.org/10.1186/s40795-015-0026-6

[13] DHS (2011) Ethiopia Demographic and Health Survey: Preliminary Report. Central Statistical Agency and Measure, Addis Ababa, Ethiopia and Calverton, USA.

[14] Belachew, T. and Legesse, Y. (2006) Risk Factors for Anemia among Pregnant Women Attending Antenatal Clinic at Jimma University Hospital, Southwest Ethiopia. Ethiopian Medical Journal, 44, 211-220. 
[15] Gies S., Brabin, B., Yassin, M. and Cuevas, L. (2003) Comparison of Screening Methods for Anemia in Pregnant Women in Awassa, Ethiopia. Tropical Medicine and International Health, 8, 301-309. http://dx.doi.org/10.1046/j.1365-3156.2003.01037.x

[16] EPHI (2013) Ethiopia National Food Consumption Survey Report. Ethiopian Public Health Institute, Addis Ababa. www.ephi.gov.et

[17] Central Statistical Authority [Ethiopia] and ORC Macro (2006) Ethiopia Demographic and Health Survey. Addis Ababa, Ethiopia and Calverton, USA: Central Statistical Agency and ORC Macro.

[18] Sifakis, S. and Pharmakides, G. (2000) Anemia in Pregnancy. Annals of the New York Academy of Sciences, 900, 125136. http://dx.doi.org/10.1111/j.1749-6632.2000.tb06223.x

[19] Velu, G., Ortiz-Monasterio, I., Cakmak, I., Hao, Y. and Signh, R. (2014) Biofortification Strategies to Increase Grain Zinc and Iron Concentrations in Wheat. Journal of Cereal Sciences, 59, 365-372. http://dx.doi.org/10.1016/j.jcs.2013.09.001

[20] Ortiz-Monasterio, J., Palacios-Rojas, N., Meng, E., Pixley, K., Trethowan, R. and Peña, R. (2007) Enhancing the Mineral and Vitamin Content of Wheat and Maize through Plant Breeding. Journal of Cereal Science, 46, 293-307. http://dx.doi.org/10.1016/j.jcs.2007.06.005

[21] Cakmak, I., Torun, A., Millet, E., Feldman, M., Fahima, T., Korol, A., Nevo, E., Braun, H. and Ozkan, H. (2004) Triticum dicoccoides: An Important Genetic Resource for Increasing Zinc and Iron Concentration in Modern Cultivated Wheat. Soil Science and Plant Nutrition, 50, 1047-1054. http://dx.doi.org/10.1080/00380768.2004.10408573

[22] Alloway, B. (2007) Zinc in Soils and Crop Nutrition. IZA Publications, International Zinc Association, Brussels.

[23] Bogdanovic, D., Ubavic, M. and Cuvardic, M. (1999) Effect of Phosphorus Fertilization on Zn and Cd Contents in Soil and Corn Plants. Nutrient Cycling in Agroecosystems, 54, 49-56. http://dx.doi.org/10.1023/A:1009779415919

[24] Prasad, R., Shivay, Y. and Kumar, D. (2014) Agronomic Biofortification of Cereal Grains with Iron and Zinc. In: Sparks, D.L., Ed., Advances in Agronomy, Vol. 125, Academic Press, Burlington, 55-91. http://dx.doi.org/10.1016/B978-0-12-800137-0.00002-9

[25] Hambidge, K., Miller, L., Westcott, J., Shang, X. and Krebs, N. (2010) Zn Bioavailability and Homeostasis. American Journal of Clinical Nutrition, 91, 1478S-1483S. http://dx.doi.org/10.3945/ajcn.2010.28674I

[26] Kuwano, M., Ohyama, A., Tanaka, Y., Mimura, T., Takaiwa, F. and Yoshida, K.T. (2006) Molecular Breeding for Transgenic Rice with Low-Phytic-Acid Phenotype through Manipulating Myo-Inositol 3-Phosphate Synthase Gene. Molecular Breeding, 18, 263-272. http://dx.doi.org/10.1007/s11032-006-9038-X

[27] Iqbal, T., Lewis, K. and Cooper, B. (1996) Phytase Activity in the Humans and Rat Intestines. Gut, 35, 1233-1236. http://dx.doi.org/10.1136/gut.35.9.1233

[28] Bindra, G., Gibson, R. and Thompson, L. (1986) [Phytate][Calcium]/[Zn] Ratios in Asian Immigrant Lacto-Ovo Vegetarian Diets and Their Relationship to Zn Nutrition. Nutrition Research, 6, 475-483. http://dx.doi.org/10.1016/S0271-5317(86)80101-4

[29] Ozturk, A., Caglar, O. and Bulut, S. (2006) Growth and Yield Response of Facultative Wheat to Winter Sowing, Freezing Sowing and Spring Sowing at Different Seeding Rates. Journal of Agronomy and Crop Science, 192, 10-16. http://dx.doi.org/10.1111/j.1439-037X.2006.00187.x

[30] Graham, R., Welch, R., Saunders, D., et al. (2007) Nutritious Subsistence Food Systems. Advance in Agronomy, 92, 174. http://dx.doi.org/10.1016/S0065-2113(04)92001-9

[31] Impa, S. and Johnson-Beebout, S.E. (2012) Mitigating Zinc Deficiency and Achieving High Grain Zn in Rice through Integration of Soil Chemistry and Plant Physiology Research. Plant and Soil, 361, 3-41. http://dx.doi.org/10.1007/s11104-012-1315-3

[32] Zhang, Y., Shi, R., Rezaul, K.M., Zhang, F. and Zou, C. (2010) Iron and Zinc Concentrations in Grain and Flour of Winter Wheat as Affected by Foliar Application. Journal of Agriculture and Food Chemistry, 58, 12268-12274. http://dx.doi.org/10.1021/jf103039k

[33] Gomez-Galera, S., Rojas, E., Sudhakar, D., Zhu, C., Pelacho, A., Capell, T. and Christou, P. (2010) Critical Evaluation of Strategies for Mineral Fortification of Staple Food Crops. Transgenic Research, 19, 165-180. http://dx.doi.org/10.1007/s11248-009-9311-y

[34] Quisumbing, A., Brown, L., Feldstein, H., Haddad, L. and Pena, C. (1995) Women: The Key to Food Security. IFPRI Food Policy Report, Washington DC.

[35] Weingärtner, L. (2005) The Concept of Food and Nutrition Security. In: Klennert, K., Ed., Achieving Food and Nutrition Security: Actions to Meet the Global Challenge, InWEnt, Starnberg, 1-28.

[36] Hotz, C. (2009) The Potential to Improve Zinc Status through Biofortification of Staple Food Crops with Zinc. Food and Nutrition Bulletin, 30, S172-S178. http://dx.doi.org/10.1177/15648265090301S109 
[37] Cakmak, I. (2008) Enrichment of Cereal Grains with Zinc: Agronomic or Genetic Biofortification? Plant and Soil, 302, 1-17. http://dx.doi.org/10.1007/s11104-007-9466-3

[38] Haider, B. and Bhutta, Z. (2009) The Effect of Therapeutic Zinc Supplementation among Young Children with Selected Infections: A Review of the Evidence. Food and Nutrition Bulletin, 30, S41-S49. http://dx.doi.org/10.1177/15648265090301S104

[39] Sesikaran, B. and Ranganathan, S. (2009) Salt Fortification for Micronutrient Security. Symposium on Nutrition Security for India - Issues and Way Forward, Indian National Science Academy, New Delhi, 3-4 August 2009, 15-16.

[40] Gibson, R. and Anderson, V. (2009) A Review of Interventions Based on Dietary Diversification or Modification Strategies with the Potential to Enhance Intakes of Total and Absorbable Zinc. Food and Nutrition Bulletin, 30, S108S143. http://dx.doi.org/10.1177/15648265090301S107

[41] Swaminathan, M. (2002) Agricultural Progress and Nutritional Security. Inaugural Address. 2nd International Agronomy Congress on Balancing Food and Environmental Security-A Continuing Challenge, New Delhi, 26-30 November 2002, 22.

[42] White, P. and Broadley, M. (2005) Biofortifying Crops with Essential Mineral Elements. Trends in Plant Science, 10, 586-593. http://dx.doi.org/10.1016/j.tplants.2005.10.001

[43] Stein, A.J. (2010) Global Impacts of Human Mineral Nutrition. Plant and Soil, 335, 133-154. http://dx.doi.org/10.1007/s11104-009-0228-2

[44] Ramaswami, B. (2007) Biofortified Crops and Biotechnology: A Political Economy Landscape for India. AgBioForum, 10, $170-177$.

[45] Murray-Kolb, L., Takaiwa, F., Goto, F., Yoshihara, T., Theil, E. and Beard, L. (2002) Transgenic Rice is a Source of Iron for Iron-Depleted Rats. Journal of Nutrition, 132, 957-960.

[46] Takahashi, M., Nakanishi, S., Kawasaki, S., Nishizawa, N. and Mori, S. (2001) Enhanced Tolerance of Rice to Low Iron Availability in Alkaline Soils Using Barley Nicotianamine Aminotransferase Genes. Natural Biotechnology, 19, 466-469. http://dx.doi.org/10.1038/88143

[47] Nestel, P., Bouis, H., Meenakshi, J. and Pfeiffer, W. (2006) Biofortification of Staple Food Crops. Journal of Nutrition, 136, 1064-1067.

[48] Conti, M., Cubadda, F. and Carcea, M. (2000) Trace Metals in Soft and Durum Wheat from Italy. Food Additives \& Contaminants, 17, 45-53. http://dx.doi.org/10.1080/026520300283577

[49] Ficco, D., Riefolo, C., Nicastro, G., De Simone, C., Di Gesu, A., Beleggia, R., Platani, C., Cattivelli, L. and De Vita, P. (2009) Phytate and Mineral Elements Concentration in a Collection of Italian Durum Wheat Cultivars. Field Crops Research, 111, 235-242. http://dx.doi.org/10.1016/j.fcr.2008.12.010

[50] Velu, G., Singh, R., Huerta-Espino, J., Peña-Bautista, R., Arun, B., Mahendru-Singh, A., Yaqub Mujahid, M., Sohu, V., Mavi, G., Crossa, J., et al. (2012) Performance of Biofortified Spring Wheat Genotypes in Target Environments for Grain Zinc and Iron Concentrations. Field Crops Research, 137, 261-267. http://dx.doi.org/10.1016/j.fcr.2012.07.018

[51] Ozturk, L., Torun, B., Ozkan, H., Kaya, Z. and Cakmak, I. (2001) Tolerance of 65 Durum Wheat Genotypes to Zinc Deficiency in a Calcareous Soil. Journal of Plant Nutrition, 24, 1831-1847. http://dx.doi.org/10.1081/PLN-100107315

[52] Monasterio, I. and Graham, R. (2000) Breeding for Trace Minerals in Wheat. Food and Nutrition Bulletin, 21, $392-396$. http://dx.doi.org/10.1177/156482650002100409

[53] Zhao, F., Su, Y., Dunham, S., Rakszegi, M., Bedo, Z., McGrath, S. and Shewry, P. (2009) Variation in Mineral Micronutrient Concentrations in Grain of Wheat Lines of Diverse Origin. Journal of Cereal Science, 49, 290-295. http://dx.doi.org/10.1016/j.jcs.2008.11.007

[54] Abrar, H., Larsson, H., Kuktaite, R. and Johansson, E. (2010) Mineral Composition of Organically Grown Wheat Genotypes: Contribution to Daily Minerals Intake. International Journal of Environmental Research and Public Health, 7, 3442-3456. http://dx.doi.org/10.3390/ijerph7093442

[55] Cakmak, I., Ozkan, H., Braun, R., Welch, R. and Romheld, V. (2007) Zn and Iron Concentrations in Seeds of Wild, Primitive, and Modern Wheats. Food and Nutrition Bulletin, 21, 401-403. http://dx.doi.org/10.1177/156482650002100411

[56] Amede, T., Stroud, A. and Aune, J. (2004) Advancing Human Nutrition without Degrading Land Resources through Modeling Cropping Systems in the Ethiopian Highlands. Food and Nutrition Bulletin, 25, 344-353. http://dx.doi.org/10.1177/156482650402500404

[57] Valéria, A., Guimarães, P., Queiroz, L., Guedes, E., Vasconcelos, V., Guimarães, L., Ribeiro, P. and Schaffert, R. (2010) Iron and Zinc Availability in Maize Lines. Food Science and Technology (Campinas), 31, 577-583.

[58] Badigannavar, A., Girish, G., Ramachandran, V. and Ganapathi, T. (2016) Genotypic Variation for Seed Protein and Mineral Content among Post-Rainy Season-Grown Sorghum Genotypes. The Crop Journal, 4, 61-67. http://dx.doi.org/10.1016/j.cj.2015.07.002 
[59] Kayode, A., Linnemann, A., Hounhouigan, J., Nout, M. and Van Boekel, M. (2006) Genetic and Environmental Impact on Iron, Zinc, and Phytate in Food Sorghum Grown in Benin. Journal of Agriculture and Food Chemistry, 54, $256-262$. http://dx.doi.org/10.1021/jf0521404

[60] Alloway, B. (2009) Soil Factors Associated with Zn Deficiency in Crops and Humans. Environmental Geochemistry and Health, 31, 537-548. http://dx.doi.org/10.1007/s10653-009-9255-4

[61] Impa, S., Morete, M., Ismail, A., Schulin, R. and Johnson-Beebout, S. (2013) Zn Uptake, Translocation, and Grain Zn Loading in Rice (Oryza sativa L.) Genotypes Selected for Zn Deficiency Tolerance and High Grain Zn. Journal of Experimental Botany, 64, 2739-2751. http://dx.doi.org/10.1093/jxb/ert118

[62] Clark, R. (1983) Plant Genotype Differences in the Uptake, Translocation, Accumulation, and Use of Mineral Elements Required for Plant Growth. In: Sarić, M.R. and Loughman, B.C., Eds., Genetic Aspects of Plant Nutrition, Vol. 8, Springer, Dordrecht, 49-70. http://dx.doi.org/10.1007/978-94-009-6836-3_5

[63] Hamilton, M., Westermann, D. and James, D. (1993) Factors Affecting Zinc Uptake in Cropping Systems. Soil Science Society of America Journal, 57, 1310-1315. http://dx.doi.org/10.2136/sssaj1993.03615995005700050025x

[64] Jaffe, G. (2005) Withering on the Vine: Will Agricultural Biotech’s Promises Bear Fruit? Center for Science in the Public Interest, Washington DC.

[65] Mathpal, B., Srivastava, P., Shankhdhar, D. and Shankhdhar, S. (2015) Zinc Enrichment in Wheat Genotypes under Various Methods of Zinc Application. Plant, Soil and Environment, 61, 171-175. http://dx.doi.org/10.17221/41/2015-PSE

[66] Mao, H., Wang, J., Zan, Y., Lyons, G. and Zou, C. (2014) Using Agronomic Biofortification to Boost Zinc, Selenium, and Iodine Concentrations of Food Crops Grown on the Loess Plateau in China. Journal of Soil Science and Plant Nutrition, 14, 459-470. http://dx.doi.org/10.4067/s0718-95162014005000036

[67] Yilmaz, A., Ekiz, H., Torun, B., Gultekin, I., Karanlik, S., Bagci, S. and Cakmak, I. (1997) Effect of Different Zinc Application Methods on Grain Yield and Zinc Concentration in Wheat Grown on Zinc-Deficient Calcareous Soils in Central Anatolia. Journal of Plant Nutrition, 20, 461-471. http://dx.doi.org/10.1080/01904169709365267

[68] Narwal, R., Malik, R. and Dahiya, R. (2010) Addressing Variations in Status of a Few Nutritionally Important Micronutrients in Wheat Crop. 19th World Congress of Soil Science, Soil Solutions for a Changing World, Brisbane, 1-6 August 2010, 1-3.

[69] Cakmak, I., Pfeiffer, W. and McClafferty, B. (2010) Biofortification of Durum Wheat with Zinc and Iron. Cereal Chemistry, 87, 10-20. http://dx.doi.org/10.1094/CCHEM-87-1-0010

[70] Gomez-Beccerra, H., Yazici, A., Ozturk, L., Budak, H., Peleg, Z., Morgounov, A., Fahima, T., Saranga, Y. and Cakmak, I. (2010) Genetic Variation and Environmental Stability of Grain Mineral Nutrient Concentrations in Triticum dicoccoides under Five Environments. Euphytica, 171, 39-52. http://dx.doi.org/10.1007/s10681-009-9987-3

[71] Brown, K., Hambidge, K. and Ranum, P. (2010) Zinc Fortification of Cereal Flours: Current Recommendations and Research Needs. Food and Nutrition Bulletin, 31, S62-S74. http://dx.doi.org/10.1177/15648265100311S106

[72] Aciksoz, S., Yazici, A. and Cakmak, I. (2010) Effect of Nitrogen and Iron Fertilizers on Grain Concentration of Iron in Wheat. 19th World Congress of Soil Science, Soil Solutions for a Changing World, Brisbane, 1-6 August 2010, 7-8.

[73] Ghafari, H. and Razmjoo, J. (2015) Response of Durum Wheat to Foliar Application of Varied Sources and Rates of Iron Fertilizers. Journal of Agricultural Science and Technology, 17, 321-331.

[74] Zeidan, M., Manal, F. and Hamouda, H. (2010) Effect of Foliar Fertilization of Fe, Mn and Zn on Wheat Yield and Quality in Low Sandy Soils Fertility. World Journal of Agricultural Sciences, 6, 696-699.

[75] Cakmak, I. (2012) Zinc Fertilizer Strategy for Improving Yield. The Fluid Journal, 20, 4-7.

[76] Maralian, H. (2009) Effect of Foliar Application of Zn and Fe on Wheat Yield and Quality. African Journal of Biotechnology, 8, 6795-6798.

[77] Haslett, B., Reid, R. and Rengel, Z. (2001) Zinc Mobility in Wheat: Uptake and Distribution of Zinc Applied to Leaves or Roots. Annals of Botany, 87, 379-386. http://dx.doi.org/10.1006/anbo.2000.1349

[78] Bouis, H. and Welch, R. (2010) Biofortification-A Sustainable Agricultural Strategy for Reducing Micronutrient Malnutrition in the Global South. Crop Science, 50, 20-32.

[79] Velu, G., Singh, R., Huerta-Espino, J., Peña, J. and Ortiz-Monasterio, I. (2011) Breeding for Enhanced Zinc and Iron Concentration in CIMMYT Spring Wheat Germplasm. Czech Journal of Genetics and Plant Breeding, 47, S174-S177.

[80] Gao, X., Lukow, O. and Grant, C. (2012) Grain Concentrations of Protein, Iron and Zinc and Bread Making Quality in Spring Wheat as Affected by Seeding Date and Nitrogen Fertilizer Management. Journal of Geochemical Exploration, 121, 36-44. http://dx.doi.org/10.1016/j.gexplo.2012.02.005

[81] Narwal, R., Dahiya, R., Malik, R. and Kala, R. (2012) Influence of Genetic Variability on Zinc, Iron and Manganese Responses in Wheat. Journal of Geochemical Exploration, 121, 45-48. http://dx.doi.org/10.1016/j.gexplo.2012.06.006 
[82] Rawat, N., Tiwari, V., Chhuneja, P. and Dhaliwal, S. (2009) Evaluation and Utilization of Aegilops and Wild Triticum Species for Enhancing Iron and Zinc Content in Wheat. Genetic Resources and Crop Evolution, 56, 53-64. http://dx.doi.org/10.1007/s10722-008-9344-8

[83] Aggett, P. (1983) Acrodermatitis Enteropathica. Journal of Inherited Metabolic Disease, 6, 39-43. http://dx.doi.org/10.1007/BF01811322 